\title{
非集計行動モデルによる多次元選択行動の分析* Disaggregate Behavioral Model and Multidimensional Choice
}

\author{
原田昇 ${ }^{* *}$
}

By Noboru HARATA

はじめに

「交通の現象を交通流としてではなく，個人行動 の積み上げとして捉え直すてとによって交通計画に 何か新しい展開が生まれるのではないか.」,てれが 私が非集計行動モデルの研究に抱いた予感であり, 以来, 今日までの研究の大筋を一言で言うならば, 「ある合理的な理論に基づいて交通行動を理解しよ うとするとと」であった。したがって, 研究のスタ イルは,「確率効用理論という合理的理論とその交 通行動への適用可能性を実際の交通行動への適用を 通して理解する」と言う実証的なすのとなった ${ }^{1)}$. 例えば, 鉄道経路 (駅と端末手段) と代表交通手段 の同時選択行動は, 重要な分析課題であるにあかか わらず集計型モデルでは分析困難な現象であったが, 非集計行動モデルによる分析は実用的と言えるに至 っている2). また, 種々の改良モデルが提案されて いるが，ロジットモデルのIIA 特性を緩和した NESTED LOGIT (NL) モデルは, 目的地と交通手段 の同時選択などの多次元選択行動の分析を改善する 上で重要なととが明らかになっている3゙.

\footnotetext{
*キーワード : 交通需要分析, 非集計行動モデル, 多 次元選択

**正会員 工博 東京大学工学部助手
}

こてでは, これらの要点を, 非集計行動モデルに よる多次元選択行動分析に係わる理論的改良と適用 事例のレビューとしてまとめるものである.

以下では, 個人選択理論の概要, 個人行動として 交通を捉える際の基本的概念を示したのち, 多次元 選択モデルにおける合成変数の形とパラメータの意 味をNLモデルとの関係で整理する。そして, 適用 によって得られた知見を整理し, 今後の研究の展望 をまとめる.

\section{1. 個人選択理論の概要}

例えば，「Aさんが自家用車で通勤している。」 という交通行動については，数多くの仮説を立てる 事ができる。

・バスや鉄道に比べて, 費用は少し多くかかるが 非常に速いので利用する。

・バスや鉄道に比べて, 高くてやや遅いが, プラ イバシーが保てるので利用する。

・仕事で自家用車を使うので，仕方なく利用する. ・子供を送り迎えするために，利用する.

・運転することが好きなので, 利用する. であり, 実際の理由あ多種多様である.

これらはいずれす, 「意思決定者が, 選択肢の中 から, あるルールにしたがって選択を行う」, とい 
うフレームで考える事ができるが, 意思決定者, 選 択肢, ルールの 3 要素には多くのバリエーションが ある．意思決定者は多くの場合個人であるが，世帯 や企業も考えられる，考慮される選択肢は，利用可 能性亡重要度により異なっており,ルールには, 合。 理的なむのから全くのランダム，あるいは偏見によ る一意的なあのまで考える事ができる.

非集計行動モデルは, 適用性の高い組み合わせと して,「個人等の意思決定者が, 利用可能な選択肢 の中から, 合理的選択により, 最も望ましい選択肢 を選択する.」，之考えるあのである.すなわち， 個人の状況によって「利用可能な選択肢 (CHOICE $\mathrm{SET}) 」 か ゙$ 限定され, 次にその中から最も望ましい 選択肢を選ぶとしているのである。乙れに関しては， 3 点指摘したい.

ひとつは, 利用可能な選択肢についてである. 適 用事例の中には，乙れら 2 つのプロセスを 1 つのモ デルで表わすむのも多いが, 現実には, 利用可能な 選択肢がかなり限定される事が多く, 政策の影響範 囲を誤らないためには，自由な選択に対する制約条 件の有無を十分に考慮する必要がある。例えば, 交 通手段選択では, 保有, 免許, 利用距離限界, サー ビス時間帯による制約が重要である。

次は，選択肢の望ましさであるが，時間，費用， 快適性などの総合指標 (通常は線形和, LINEAR IN PARAMETER注 1)）を作成し,てれを「効用」 と呼ぶことにしている．乙れは，一般化費用の概念 を拡張したものと考えると理解しやすい.

最後に, 合理的なルールであるが, 非集計行動モ デルは, 効用理論の中の確率効用理論より, 導出す るととができる4),5)。これは, 最あ望ましい選択肢 を常に利用すると考える決定論的効用理論に比べる 之，同一個人が同一条件下で異なる反応をする可能 性を認めており，適用性が高くなっている。

乙れを, 選択確率 $P$, 効用 $U$, 個人 $n$ の選択肢集 合 $J$, 選択肢 $i, j$ を用いて式で示すと, “個人 $n$ が選 択肢 $i$ を選択する確率 $P_{i n}$ は,

$$
P_{i n}=\operatorname{Prob}\left[U_{i n}>U_{j n}, j \in J_{n}\right] \cdots(1-1)
$$

となる．また，効用すべて $(U)$ を測定するてとは 困難であり, 測定可能な確定項 $(V)$ と測定不可能 な誤差項 $(e)$ との和として次のように記述する.

$$
U_{i n}=V_{i n}+e_{i n}
$$

式 (1-2)で，誤差項の分布形は未知であるが, 適切な分布を仮定し, 式 (1-1) に代入し密度関数 の積分計算を行う事によって, 非集計行動モデルの 関数形を導出する事ができる，最む一般的には，誤 差項はいくつもの誤差の同時分布であるととから正 規分布と考えられ，その結果として，プロビットモ デルが得られる。しかし，パラメー夕推定が困難で あり，誤差項を独立で同一な Gumbell 分布と仮定 して得られるロジットモデルの方が適用が進んでい る.な抢，正規分布と Gumbell 分布の関係，モデ ルの導出過程, 最尤法によるパラメータの推定, 集 計予測方法等については, 文献 6 )を参照されたい.

\section{2. 個人行動としての交通}

交通に関する選択は, 交通を行うか否か ( 交通発 生頻度), いつ行くか (出発時刻), どてへ行くか (目的地), どの交通機関を用いるか (交通機関), どの経路を用いるか（経路）といった多くの次元を 含んでおり, 交通行動はこれらの選択群の組み合わ せ ( A BUNDLE OF CHOICE) によって決定さ れる多次元選択行動として捉えるととができる7),8). また，長期的には，居住地の選択や自動車保有台数 の選択とあ関連している．膨大な組み合わせを含む てれらの選択行動を分析するための考え方を 3 点指 摘したい。ひとつは，時間的安定性により，てれら の選択次元を分類しヒエラルキーを設定する事に ある．例えば, SAN FRANCISCO 湾岸地域で開 発された非集計行動モデルによる予測モデル (MTC) 体系では, 土地利用モデルによる都市開発決定の予 測と, 非集計行動モデルによるモビリティ選択と交 通選択の 3 段階構造を用いている。 また, BRAZIL において非集計行動モデルによる予測体系を開発し 
た例 ${ }^{10)}$ ，短期交通政策評価モデルを開発した例 ${ }^{11)}$

に, ヒエラルキー適用の典型をみることができる。

次は, 同時選択モデルの段階推定による計算負荷 の軽減である。例えば, 目的地 $(d)$ と交通手段 $(m)$ の同時選択モデル $P(m, d)$ は, 次式のように条件 付き確率 $P(m \mid d)$ と周辺確率 $P(d)$ の積に展開 し，ロジットモデルの場合には，2段階に分けて推 定することができる ${ }^{12)}$. 乙の時, 各段階で取り扱う 選択肢の数が大幅に減少するため, 推定が容易にな る.

$$
\begin{aligned}
P(m, d) & =P(d) \cdot P(m \mid d) \\
& =P(m) \cdot P(d \mid m) \cdots(2-1)
\end{aligned}
$$

最後は, 政策評価モデルの開発についてであるが, 対象とする政策の影響がどてまで及ぶのか, ある次 元をモデルに取り入れる事に実用的な意味があるの か, を考える事によって, 分析対象とするべき交通 行動の範囲を的確に限定することが重要となる．例 えば，買い物トリップに関して，交通機関選択と目 的地や交通発生頻度の選択を組み合わせた同時選択 モデルを用いる例が多いが, これは, 都心部の駐車 規制が都心部への買い物回数をへらしたり郊外ショ ッピングセンターに買い物目的地を変更させたりす る，という事が考えられる場合に有用である.

\section{3. 多次元選択と合成変数}

自動車保有と通勤手段, 頻度と目的地と交通手段 といった，多次元にわたる選択行動のモデル化は， 同時選択モデルの段階推定により容易になったが, 次の課題は, 条件付き確率の影響を周辺確率に持ち 込む「合成変数 ( COMPOSITE VARIABLE)」 の定式化であった。

例えば，目的地選択モデル $P(m)$ の推定におい て，その目的地まで利用可能な交通手段の効用を合 成する方法については, 種々の方法が使われていた。 効用最大の交通手段によって代表させる方法, 各手 段の効用を選択確率 $P(m \mid d)$ により重み付け平均
して用いる方法などであり，直観的には納得のいく 方法であった。

しかし, Manheim ${ }^{13)}$ によって, 同時選択モデル の段階推定において整合性を保つには, 確率に関す る次の二式を満足する合成変数を導入することが示 され，ロジットモデルに関しては, 合成変数はLOGSUM の式形になるてとが明らかとなった。

$$
\begin{aligned}
& P(d)=\sum_{m} P(m, d) \text { [周辺確率の算出] } \\
& P(m \mid d)=P(m, d) / P(d)
\end{aligned}
$$

[条件付き確率の算出] $(3-2)$

例えば，目的地と交通手段の選択から得られる効 用 $V_{i}$ を, 目的地のみ, 手段のみ, 目的地と手段の 双方に関連した効用, $V_{d}, V_{m}, V_{d m}$, に分けて, 以 下のように表記すると,

$$
V_{i}=V_{d}+V_{m}+V_{d m}
$$

目的地と交通手段の同時選択確率を表わすロジット モデルは,

$$
P(d, m)=\frac{e^{V d+V m+V d m}}{\sum_{d} \sum_{m} e^{V d+V m+V d m}} \cdots \cdots(3-4)
$$

となり, 以下の手順で, 式形を決定できる.

はじめに, 式 (3-1) より $P(d)$ を決める.

$$
P(d)=\frac{e^{V d} \sum_{m^{\prime}} e^{V m^{\prime}+V d m^{\prime}}}{\sum_{d^{\prime}} e^{V d^{\prime}} \sum_{m^{\prime}} e^{V m^{\prime}+V d m^{\prime}}}
$$

ここで, 交通手段 $m$ に関連する効用を合成変数 $\Lambda$ で表わすと,

$$
\begin{aligned}
& \Lambda_{d}=\ln \left(\sum_{m^{\prime}} e^{V m^{\prime}+V d m^{\prime}}\right) \\
& P(d)=\frac{e^{V d+\Lambda d}}{\sum_{d^{\prime}} e^{V d^{\prime}+\Lambda d^{\prime}}} \cdots
\end{aligned}
$$

となる， $\Lambda_{d}$ の形から合成变数は, LOGSUM 変数 とも呼ばれている.

次に, 式 (3-3) と (3-6) を式 (3-2)に代入し て, 
原田：

$$
P(m \mid d)=\frac{e^{V m+V d m}}{\sum_{m^{\prime}} e^{V m^{\prime}+V d m^{\prime}}}
$$

が得られる。

これらの式は, 同時型ロジットモデルでは, 条件 付き確率と周辺確率もロジットモデルで表わされる ことを示している.したがって，交通行動分析では 条件付き確率を取り扱うことが多いが，ロジットモ デルを用いることができる，例えば，通勤交通手段 選択は居住地，就業地，自動車保有を既決定とする 条件付き選択行動として, ロジットモデルを用いて 分析することができる.

\section{4. 合成変数の解釈}

ここでは, LOGSUMで表わされる合成変数の持 つ意味を整理してみる.

例えば，目的地と交通手段の同時選択ロジットモ デルにおいて, 目的地 $d$ への交通手段 $m$ を含む選択 肢グループ $M_{n d}$ の最大効用は注2），

$$
\begin{aligned}
\max _{m \in M n d}\left(U_{m \mid d}\right) & =\max _{m \in M n d}\left(V_{m}+V_{d m}+\varepsilon_{d m}\right) \\
& =\ln \left(\sum e_{m \in M n d}^{V m^{\prime}+V d m^{\prime}}\right)+\varepsilon_{d} \\
& =\Lambda_{d}+\varepsilon_{d} \cdots \cdots \cdots \cdots \cdots
\end{aligned}
$$

となり, 合成変数は最大効用の確定項と一致する. したがって, 合成変数は, 特定の選択肢グループか ら得られる最大効用の期待値のメジャーとして用い る事ができる。

ロジットモデルに関する合成変数については, さ らに，選択肢ならびに効用値の増加に対して非減少 であるてとが示されている ${ }^{14)}$. すなわち, 既存の選 択肢の改善効果と同様に, 利用可能な選択肢の増加 （＝選択の自由度の増大）による効果を, 合成変数 值の変化によって測定することができる.

また, 特定目的地へ利用可能な交通手段の効用を 合理的に合成した值として $\Lambda_{d}$ をアクセシビリティ の指標として用いる事ができる. 合成変数の值は, 個々のサンプルにより異なったものとなるが，それ
らを集計する事によって, 地区による違いを示すと とができる15).

さらに, 合成変数 $\Lambda$ は, 消費者余剰の指標として 用いる事ができる，選択モデルは，ある選択肢に対 する個人の需要関数とみなしうる。したがって, 効 用が $V_{n}^{1}$ から $V_{n}^{2}$ へ変化した場合の個人の消費者余 剩の変化 $\Delta S$ は,

$$
\Delta S=\sum_{i \in J n} \int_{\boldsymbol{V}_{n}^{1}}^{V_{n}^{2}} P(i) d \boldsymbol{V}
$$

となる.ロジットモデルの場合は, この積分を解く ことが可能であり, 次式が得られる16).

$$
\Delta S=\ln \left(\sum_{i \in J n} e^{V i n}\right)-\ln \left(\sum_{i \in J n} e^{V i n}\right)
$$

消費者余㮃の変分が合成変数値の変分により与え られることが分かる。

\section{5. 合成変数のパラメータ}

合成変数の形が決定したうえでの課題は, 合成変 数のパラメータの取りうる值とその解釈であった. 合成変数の係数が 1.0 のとき同時型と一致するので あるが, 実際に段階推定すると, 合成变数の係数は 1 にはならないてと, 推定順序により異なる係数が 推定されることが示された。 McFadden ${ }^{17)}$ は，乙 の係数が 2 を越えてはならないことを示したが, $\mathrm{NL}$ モデルの開発によって，乙の係数は 0 と 1 の間 にあるべきことが明らかとなった。なお, 確率効用 理論からの NL モデルの導出は, William 等を参照 されたい(3),6),18),19).

ここでは，鉄道ルートを含む選択ッリー（図一-1） を用いて, 合成変数とそのパラメータの実用的な意 味を例示する。

図 - 1 の選択ッリーに相当する NL モデルは,

$$
\begin{aligned}
& P(l \mid r)=e^{\lambda_{1} V_{r l}} / \sum_{l^{\prime}} e^{\lambda_{1} V_{r l^{\prime}}} \cdots \cdots \cdots \\
& P(m)=e^{\lambda_{2}\left(V_{m}+V_{m *}\right)} / \sum_{m^{\prime}-1}^{3} e^{\lambda_{2}\left(V_{m^{\prime}}+V_{m^{\prime}}\right)}
\end{aligned}
$$




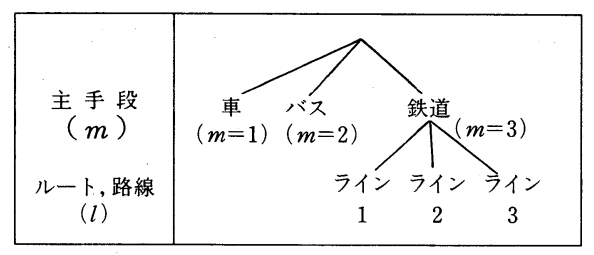

図一１鉄道 3 ルートを含む選択ツリー

ただし，

$$
V_{m^{\prime} *}= \begin{cases}0 & m^{\prime}=1,2 \\ \frac{1}{\lambda_{1}} \ln \left(\sum_{l^{\prime}-1}^{3} e^{\lambda_{1} V_{r l} \prime}\right), & m^{\prime}=3\end{cases}
$$

$$
\lambda_{2}<\lambda_{1}
$$

この例を用いて 4 点指摘したい.

第 1 は, 合成変数について, 式 $(5-3)$ の $V_{3}$ *を 展開する ${ }^{18)}$ と,

$$
\begin{aligned}
V_{3 *} & =\frac{1}{\lambda_{1}} \ln \left(\frac{1}{P_{\max \mid r}} e^{\lambda_{1} v_{r \cdot \max }}\right) \\
& =-\frac{1}{\lambda_{1}} \ln P_{\max \mid r}+V_{r \cdot \max }
\end{aligned}
$$

ただし, $P_{\max \mid r}=\frac{e^{\lambda_{1} V_{r \cdot \max }}}{\sum_{l^{\prime}} e^{\lambda_{1} V_{r l^{\prime}}}}$

ここに, $V_{r \cdot \max }$ : 効用最大の鉄道経路の $V_{r \cdot l}$

したがって, 効用最大の経路で代表される $\left(V_{3} *=\right.$

$\left.V_{r \cdot \max }\right)$ 場合に比べると, “ $-\frac{1}{\lambda_{1}} \ln P_{\max / r}(\geq 0) ”$ は修正項と考えられる $\left(V_{r}\right.$.l が時間のみで構成さ れる場合, 効用最大の経路はミニマムパスを意味 する）.

$$
V_{\text {rail }}=V_{3}+V_{3 *}
$$

とおき, $\lambda_{2}=1$ に固定すると $V_{\text {rail }}$ は,

・効用の誤差項をすべて独立であるとする（この場 合, $\lambda_{1}=\lambda_{2}=1$ ) ロジットモデルのときに, 最 大となること．

・鉄道経路間の効用の誤差項は完全に相関をむつ
( この場合， $\lambda_{1}=\infty$ ) Maximum モデルのときに， 最小となるとと。

がわかる20). したがって, 類似性の大小に応じて, $\lambda_{2} / \lambda_{1}$ を[0,1]に定めればよいことがわかる. また, ルート間の効用 $V_{r l}$ がすべて等しい場合，あ るいは, ルート数 $N$ のみが既知でそれらの効用は 等しいと仮定する場合には,

$$
\begin{aligned}
V_{3 *} & =\frac{1}{\lambda_{1}} \ln \left(N \cdot e^{\lambda_{1} V, l}\right) \\
& =V_{r l}+\frac{1}{\lambda_{1}} \ln N
\end{aligned}
$$

となり, ロジットモデルと比べて,$\frac{1}{\lambda_{1}} \ln N$ を導入 した形になる。

次に弾力性について,

$$
\begin{aligned}
& V_{m}=\sum_{n=1}^{N} \theta_{n} Y_{m n} \\
& V_{3 l}=\sum_{k=1}^{k} \beta_{k} X_{l k}
\end{aligned}
$$

と置いて, 式 (5-1), (5-2) より弾力性を算出す ると,

$$
\begin{aligned}
& \boldsymbol{E}_{x_{l k}}^{P(r)}=X_{l k} \cdot(1-P(r)) \cdot P(l \mid r) \cdot \lambda_{2} \cdot \beta_{k} \\
& (5-9) \\
& \boldsymbol{E}_{X_{l k}}^{P(m)}=X_{l k} \cdot(-P(r)) \cdot P(l \mid r) \cdot \lambda_{2} \cdot \beta_{k} \\
& (m \neq r) \\
& (5-10) \\
& \boldsymbol{E}_{Y_{m n}}^{P(m)}=Y_{m n} \cdot(1-P(m)) \cdot \lambda_{2} \cdot \theta_{n} \\
& (m \neq r) \\
& \boldsymbol{E}_{Y_{m n}}^{P(r)}=Y_{m n} \cdot(-P(m)) \cdot \lambda_{2} \cdot \theta_{n}
\end{aligned}
$$

となる. 合成変数に含まれる $X_{l k}$ の変化に関する弾 力性式 (5-9)，(5-10) は, $P(l \mid r)(\leq 1)$ によ って割引かれることがわかる。ただし，乙の性質は， 段階型ロジットモデルと共通である. 式 (5-9) （5-12）の弾力性をみると， $\lambda_{2}$ については, 負 になると，「鉄道経路の改善がされたのに，鉄道経 路全体の利用率が低下する」という矛盾が生じてく ることがわかる。しかし， $\lambda_{2}$ と $\lambda_{1}$ の大小関係につ いては, この 4 式をみると, 弾力性の符号からみ 
た制約はない。

そてで， $\lambda_{2} / \lambda_{1} \leq 1$ の意味を考えてみよう. IIA 特性は, “赤バスー青バス”問題で明らかなように， 弾力性の点でいえば, 類似性の大小によらず, すべ ての選択肢に対する交差弾力性が一定になることに 問題がある．NL モデルでは，類似性の強い選択肢 に対する交差弾力性が相対的に大きくなるはずであ る. 乙の例でいえば, 鉄道経路 $l$ の属性 $X_{l k}$ に関し $\tau$, 鉄道経路 $l^{\prime}$ 亿対する交差弾力性 $\boldsymbol{E}_{x_{l k}}^{P\left(l^{\prime} \mid r\right)}$ が, 鉄 道以外の交通手段に対する弾力性 $\boldsymbol{E}_{X_{l k}}^{P(m)}(m \neq r)$ 亿 等しいか, 大きくなるはずである.すなわち,

$$
\boldsymbol{E}_{x_{l k}}^{P\left(l^{\prime} \mid r\right)} / \boldsymbol{E}_{x_{l k}}^{P(m)} \geq 1 \quad(m \neq r)
$$

また，

$$
\boldsymbol{E}_{x_{l k}}^{P\left(l^{\prime} \mid r\right)}=X_{l k} \cdot(-P(l \mid r)) \cdot \lambda_{1} \cdot \beta_{k}
$$

したがって, 式 (5-10), (5-14)を式 (5-13)に 代入し、整理すると，

$$
\frac{\lambda_{2}}{\lambda_{1}}<\frac{1}{P(r)}
$$

となる。乙の式から, $P(r)$ の全域 $(0 \sim 1)$ に関 して, 式 (5-13) が常に成立するための必要十分 条件は,

$$
\frac{\lambda_{2}}{\lambda_{1}} \leq 1
$$

であるてとがわかる．したがって， $\lambda_{2} / \lambda_{1}$ の上限は， 類似性の異なる選択肢に対する交差弾力性の大小に 関連して意味づけることができる.

続いて，効用の差の分散を算定すると， $\lambda$ の二乗 と反比例する形となっている. この例では, $\lambda_{2}<$ $\lambda_{1}$ より,

$$
\begin{gathered}
\operatorname{Var}\left(V_{m}-V_{r}\right)=\frac{\pi^{2}}{3 \lambda_{2}{ }^{2}}>\frac{\pi^{2}}{3 \lambda_{1}{ }^{2}} \\
\quad=\operatorname{Var}\left(V_{r l}{ }^{\prime}-V_{r l}\right) \quad \ldots \ldots \ldots \ldots \ldots . . .
\end{gathered}
$$

したがって, 効用の差の分類のより小さい選択肢 グループを類似性が高いと呼んでいる事になる.
なお，NL モデルは，各レベルの $\lambda$ を共通として いるが，例えば，バスルート間と鉄道ルート間の効 用の差の分散を同一とする理論的根拠はない。乙の 点については, NL モデルの一般形として, TEV ( Tree Extreme Value) モデルが提案されてい $3^{21)}$.

最後に, 式 (5-7)，(5-8)を式 (5-1)，（5 -2）に代入して整理すると,

$$
P(l \mid r)=\frac{\exp \left[\sum_{k=1}^{K}\left(\lambda_{1} \beta_{k}\right) X_{l_{k}}\right]}{\sum_{l^{\prime}} \exp \left[\sum_{k=1}^{K}\left(\lambda_{1} \beta_{k}\right) X_{l^{\prime} k}\right]}
$$

$$
\begin{aligned}
& P(m)=\exp \left[\sum_{n=1}^{N}\left(\lambda_{2} \theta_{n}\right) Y_{m n}\right] / \\
& {\left[\sum_{m=1,2} \exp \left[\sum_{n=1}^{N}\left(\lambda_{2} \theta_{n}\right) Y_{m n}\right]+\right.} \\
& \left.\exp \left[\lambda_{2} \cdot \frac{1}{\lambda_{1}} \ln \left(\sum_{l^{\prime}=1}^{3} e^{\lambda_{1} v_{r l^{\prime}}}\right)\right]\right] \\
& \text { （ } m=1,2 \text { の場合） }
\end{aligned}
$$

となるが, 推定パラメータとして得られるのは, $\left(\lambda_{2} \theta_{n}\right),\left(\lambda_{1} \beta_{k}\right)$ ならびに $\left(\lambda_{2} / \lambda_{1}\right)$ であり, $\lambda_{2}$ と $\lambda_{1}$ については, その比率のみが推定される。 し たがって, $\lambda_{1}=1.0$ 等の基準を設定する必要があ る.

\section{NL モデルの適用方法}

ここでは，NL（または TEV）モデルを用いた 実証的研究のレビューに基づいて, NL モデルの適 用方法について，ロジットモデルの作成と比べて注 意するべき点を整理している，以下，作成手順別に 記述する。

\section{（1）選択ツリーの選定方法}

理論上の組合せとしては，選択肢の数が増加する に従って比較可能な選択構造の数が急速に増え $3^{22)}$. 例えば，選択肢数 4 に対して 26 の選択ッリ 一が考えられる. したがって, すべての可能性を比 
べて最適の選択ッリーを求めることは, 選択肢の数 が多い場合には実際的ではない，一方，適用例にお いてはいずれす, 数種類の選択ッリーに限定したう えで，モデルを適用し，その中で最す優れたあのを 選ぶ方法を用いている。 この限定の根拠について, Ortuzar は次の 2 点を挙げている ${ }^{23)}$.

1）選択肢相互の類似性に関する分析者の先見 ( apriori beliefs)

2）分析用データにおける層別分析の限界

てれは, 14 の研究の中で, アプリオリィに選択 ッリーを決めたうえでモデルを適用したものが 9 例 あるととからあ推し計るてとができる，また，選択 肢を次元によってまとめた選択ッリーを考える場合 には，次元の順序を変えた 2 種類の NL モデルと， MNL モデルの計 3 種類の選択ツリーを比較すれば 十分である ${ }^{8)}{ }^{24)}$. その他, 複数の選択ッリーを設 定しているあのは212,22),25), すべて交通手段の中で の類似性を検討したあのであり, 交通手段について は, 状況に応じて異なる選択ッリーが成立するてと が分かる、また, 自動車保有と車種の選択について あ, 異なる選択ッリーが検討されている33),35).

さらに, Van Der Hoorn et al. ${ }^{34)}$ の交通機関選 択の分析のように，鉄道について, アクセス部分と エグレス部分の合成変数を同時に導入するてともで きる，乙れは, 合成変数をアクセシビリティ指標と して活用したあので, 実用上の問題はない.

\section{（2） データの作成と特性変数の選択}

モデルを作成することは，アンケートで得られる 選択結果とモデルで推計される選択確率とが最む一 致するようなパラメータを求めるてとである、その ためには, 個々のサンプルについて, 選択結果とそ の説明要因となるサンプルの社会経済属性と利用可 能な選択肢のサービス特性をそろえることが必要と なる。

サンプルの抽出は原則としてランダムサンプリング を用いるが，NL モデルを作成する場合には，異な るレベルの選択肢の組合せについて，一定数のサン
プル数を確保する必要がある，例えば，駅・アクセ ス手段同時選択の場合, 駅別あるいはアクセス手段 別にみて, 分担率の小さいグループがあると, モデ ル精度に偏りが生じることになる。乙の場合, 分担 率の小さいグループが政策的にみて重要でない場合 は分析対象から除外し, 逆に, 政策的に重要な場合 は，選択結果に基づく層別ランダムサンプリングを 用いるなど，モデル作成サンプルにおける分担率の 偏りを押さえる工夫が必要である.

次に, 選択要因をどのレベルに入れるべきかにつ いては, 選択要因のレベルでとの変動を調べること によって決定するてとができる，例えば，駅とアク セス手段の同時選択において, 駅とアクセス手段の 選択から得られる効用 $V$ を式 (3-3) と同様に次式 で表わすととができる.

$$
V=V_{m}+V_{s}+V_{m s}
$$

$V_{m s}$ は，駅別にみてあアクセス手段別にみてあ 変動する变数であり, 駅までの所要時間などが考え られる. また, $V_{s}$ は, 駅別にのみ変動するあので, 同一駅への異なるアクセス手段については一定とな る变数である. 例えば, 鉄道の乗車時間が考えられ る. 最後に $V_{m}$ はアクセス手段別にのみ変動する変 数で, 自転車性別ダミーなどの固有变数が考えられ る.

$V_{m}, V_{s}, V_{m s}\left(=V_{m \mid s}=V_{s \mid m}\right)$ をどのレベル のモデルに含めるかは, 図一2に示すとおりであり, 選択要因を $V_{m}, V_{s}, V_{m s}$ 別に整理するてとによっ て, どのレベルのモデルで検討するべきかが明らか になる。

\section{（3） 尤度関数の定式化}

尤度関数の例を, 駅・アクセス手段同時選択につ いて示す. サンプル数を $N$, 駅数を $S$, アクセス 手段数を $M$ とし, サンプル, 駅, ア・クセス手段を 各々サフィックス $n, s, m$ で表すと, 尤度関数 $L^{*}$ は次式で与えられる。 
原田：

\begin{tabular}{|c|c|}
\hline モデルタイプ & デル \\
\hline $\begin{array}{l}\mathrm{P}(\mathrm{m}, \mathrm{s}) \text { 型 } \\
\text { ロジットモデル }\end{array}$ & $\mathrm{P}(\mathrm{m}, \mathrm{s})=\frac{e^{\lambda\left(v_{s}+v_{m}+v_{s m^{\prime}}\right)}}{\sum_{s^{\prime}} \sum_{m^{\prime}} e^{\lambda\left(v_{s^{\prime}}+v_{m^{\prime}}+v_{s^{\prime} m^{\prime}}\right)}}$ \\
\hline $\begin{array}{l}\mathrm{P}(\mathrm{m}, \mathrm{s})= \\
\mathrm{P}(\mathrm{s}) \cdot \mathrm{P}(\mathrm{m} \mid \mathrm{s}) \text { 型 } \\
\mathrm{NL} \text { モデル }\end{array}$ & $\begin{array}{l}\mathrm{P}(\mathrm{m}, \mathrm{s})=\frac{e^{\lambda_{1}\left(v_{\left.s+A_{s}\right)}\right.}}{\sum_{s^{\prime}} e^{\lambda_{1}\left(v_{s^{\prime}}+\Delta_{s^{\prime}}\right)}} \frac{e^{\lambda_{2}\left(v_{m}+V_{m \mid s}\right)}}{\sum_{m^{\prime}} e^{\lambda_{2}\left(v_{m^{\prime}}+v_{m^{\prime} \mid s}\right)}} \\
\text { 但し, } \Lambda_{s}=\frac{1}{\lambda_{2}} \ln \left(\sum_{m^{\prime}} e^{\lambda_{2}\left(V_{m^{\prime}}+v_{m^{\prime} \mid s^{\prime}}\right)}\right)\end{array}$ \\
\hline $\begin{array}{l}\mathrm{P}(\mathrm{m}, \mathrm{s})= \\
\mathrm{P}(\mathrm{m}) \cdot \mathrm{P}(\mathrm{s} \mid \mathrm{m}) \text { 型 } \\
\mathrm{NL} \text { モデル }\end{array}$ & $\begin{array}{l}\mathrm{P}(\mathrm{m}, \mathrm{s})=\frac{e^{\lambda_{1}\left(V_{m}+A_{m}\right)}}{\sum_{m^{\prime}} e^{\lambda_{1}\left(V_{m^{\prime}}+A_{m^{\prime}}\right)}} \frac{e^{\lambda_{2}\left(V_{s}+V_{s \mid m^{\prime}}\right)}}{\sum_{s^{\prime}} e^{\lambda_{2}\left(V_{s^{\prime}}+V_{s^{\prime} \mid m^{\prime}}\right)}} \\
\text { 但し, } \Lambda_{m}=\frac{1}{\lambda_{2}} \ln \left(\sum_{s^{\prime}} e^{\lambda_{2}\left(V_{s^{\prime}}+V_{s^{\prime} \mid m^{\prime}}\right)}\right)\end{array}$ \\
\hline
\end{tabular}

注） $s:$ 鉄道駅, $m:$ アクセス手段, $V_{i}: i$ のみに関連した効用

このとき, 駅とアクセス手段の選択から得られる効用 $V$ は次式 で表される。

$\begin{aligned} & V=V_{m}+V_{s}+V_{m s} \\ \text { ただし, } & V_{m s}=V_{m s}=V_{s m}\end{aligned}$

図 2 選択構造とモデル式一鉄道駅・アクセス手段同時選択の場合

$L^{*}=\prod_{n=1}^{N} \prod_{s=1}^{s} \prod_{m=1}^{M} P_{n}(m s)^{\delta(m s)_{n}} \quad \cdots \cdots(6-1) \quad L=L_{1}+L_{2}$

ただし，

$P_{n}(m s)$ : サンプル $n$ が選択肢 $m s$ を選ぶ確率

$\delta(m s)_{n}$ : サンプル $n$ が選択肢 $m s$ を選んだ時

1 , その他 0

これを，段階型で示すと，

$$
L^{*}=\prod_{n=1}^{N} \prod_{s=1}^{s} \prod_{m=1}^{M}\left[P_{n}(s \mid m) P_{n}(s)\right]^{\delta(m s)_{n}}
$$

両辺の対数をとると，

$$
\begin{aligned}
L= & \ln L^{*}=\sum_{n=1}^{N} \sum_{s=1}^{s} \sum_{m=1}^{M} \delta_{(m s)_{n}}\left[\ln P_{n}(s \mid m)\right. \\
& \left.+\ln P_{n}(m)\right] \quad \ldots \ldots \ldots \ldots \ldots \ldots \ldots \ldots \ldots \ldots \ldots \\
= & \sum_{n=1}^{N} \sum_{s=1}^{s} \sum_{m=1}^{M} \delta_{(m s)_{n}} \cdot \ln P_{n}(s \mid m) \\
& +\sum_{n=1}^{N} \sum_{m=1}^{M}\left(\sum_{s=1}^{s} \delta_{(m s)_{n}}\right) \cdot \ln P_{n}(m)
\end{aligned}
$$

となり，Lは, 尤度関数の和として表すてとができ る.
ただし，

$$
L_{1}=\sum_{n=1}^{N} \sum_{s=1}^{s} \sum_{m=1}^{M} \delta_{(m s)_{n}} \cdot \ln P_{n}(s \mid m)
$$

$$
L_{2}=\sum_{n=1}^{N} \sum_{m=1}^{M}\left(\sum_{s=1}^{s} \delta_{(m s)_{n}}\right) \cdot \ln P_{n}(m)
$$

\section{（4）パラメータの推定(同時推定と段階推定)}

NL モデルのパラメータ推定方法には, 同時推定 と段階推定がある. 同時推定が $L$ を最大とするパラ メー夕を同時に求めるのに対し, 段階推定は, $L_{1}$ を 最大とするパラメータを求め, このパラメータを $L_{2}$ へ代入したうえで $L_{2}$ を最大とするパラメータを求 めるあのである.

例えば, $P(m) \cdot P(s \mid m)$ 型の場合には, $P$ $(s \mid m)$ について $L_{1}$ を最大とするパラメータを推定 する. 次に, このパラメータを用いて合成変数 $\Lambda_{m}$ に含まれる $\ln \left(\sum_{s^{\prime}} e^{\left(V_{s}+V_{s} \mid m\right)}\right)$ を算出して, $P(m)$ 
について $L_{2}$ を最大とするパラメータを推定する.

理論的には, 同時推定の方が望ましいが, 計算時 間と容量の関係から, 選択ッリーが 3 レベルに及ぶ 場合には計算は容易でない。 また, 実証的に両手法 を比較した結果をみてあ, 現在のとてろその優劣は 明らかではない。

例えば, McFaddn ${ }^{21)}$ は, TEV モデルの段階 推定によって, 効用最大化理論との整合性のないパ ラメータが得られたと報告している. しかしてれに 対して, Cosselett ${ }^{25}$ ) は, 同一モデルを同時推定 ( 完 全情報最尤法 ）によって求めると, 効用最大化理論 と整合性のあるモデルが得られたと報告している. したがって, この原因のひとつは, 段階的推定手法 にあると考えることができる. NL モデル について あ, 推定手法によってパラメータが大きく変化した 例28) と, 逆に差がほとんどみられなかった例8)が報 告されており，推定手法による違いとその原因を検 討する必要がある，場合によっては，入に，類似性 の違いを調整すること以外の要因が入ってしまう可 能性は大きいと考えられる。

\section{（5）推定結果の検討方法}

モデル作成時に用いられる通常の統計的指標( $\theta=$ 0 亿対する $t$ 值, $\chi^{2}$ 值, $\rho^{2}$ 值) のほかに, NL モ デルでは以下の評価指標が用いられる.

1） $\lambda$ 比の推定值について, $\lambda=1$ に対する $t$ 值, あるいは $\chi^{2}$ 値

2）段階推定の場合，レベル $h$ での尤度を $L_{h}(\theta)$ と扔くと, NL モデル全体の精度を示 す指標として ${ }^{22)}$

$$
\begin{aligned}
& \rho^{2}=1-\sum_{h=1}^{H} L_{h}(\widehat{\theta}) / \sum_{h=1}^{H} L_{h}(0) \cdots \cdots(6-7) \\
& \rho_{c}^{2}=1-\sum_{h=1}^{H} L_{h}(\theta) / \sum_{h=1}^{H} L_{h}(C) \cdots \cdots(6-8) \\
& \text { ただし, } \widehat{\theta} \text { : 最尤推定量 }
\end{aligned}
$$

$L_{h}(C)$ ：選択肢固有定数のみを（選択肢の数 - 1 ) 個含むときの尤度

$\lambda=1$ (ロジットモデルと一致する）に対する $t$ 值を用いて, 選定されたツリー（におけるNLモ デル）の成立の有無をみた結果を 表一1「ツリーの 成立」欄にまとめている、ツリーの成立しないケー スのうち, McFadden ${ }^{26)}$ の事例は $\lambda=1$ を棄却で きなかったケースであり，ロジットモデルを用いる 方が適切である。 また, Ben-Akiva et al.の事例 ${ }^{33)}$ は， $\lambda=0$ を棄却できなかったケースであり，車購 入と車種の選択は独立したものとして扱う方が適切 である。

$\mathrm{NL}$ モデルの $\rho^{2}, \rho_{c}^{2}[$ 式 (6-7), (6-8)]は, 同 一の選択ツリーの中での変数組の選定基準として用 いるほかに，少なくとも 2 通りの使い方がある.

第 1 は, 効用最大化理論と整合するパラメーター をもつ NL モデルが異なる選択ッリーについて求め られたときの比較 22 であり，第 2 は，ロジットモ デルと NL モデルとの比較 ${ }^{23)}$ である.

\section{おわりに}

非集計行動モデルによる交通需要分析を研究した ことによる最大の成果は, 複雑な現象をある合理的 な考え方によって捉えて客観的に理解する姿勢が身 についてきたことではないかと考えている．当然の 事ながらモデルそのあのには限界があるが, その考 え方や基本的姿勢にはかなりの可能性がある.

したがって，乙こでは非集計行動モデルによる交 通需要分析について重要と考えられる概念とモデル 特性を, 多次元選択行動分析に関する研究レビュー として整理した。これらは, 非集計行動モデル分析 のみならず, 広く, 交通需要分析の発展に寄与する あのと期待している.

例えば, 都市圈交通需要分析については, 従来よ り, 定型的な四段階推定法が使われているが, 交通 行動の捉え方, 選択ツリーの在り方の多様性をみれ ば, 都市圏の持つ政策課題に応じて異なるアプロー チを検討するべきととがわかる，地方都市圏におい て自動車の効率的利用が問題とするならば, 自動車 保有や自動車の相乗りを交通サービス条件と関連付 
原田：

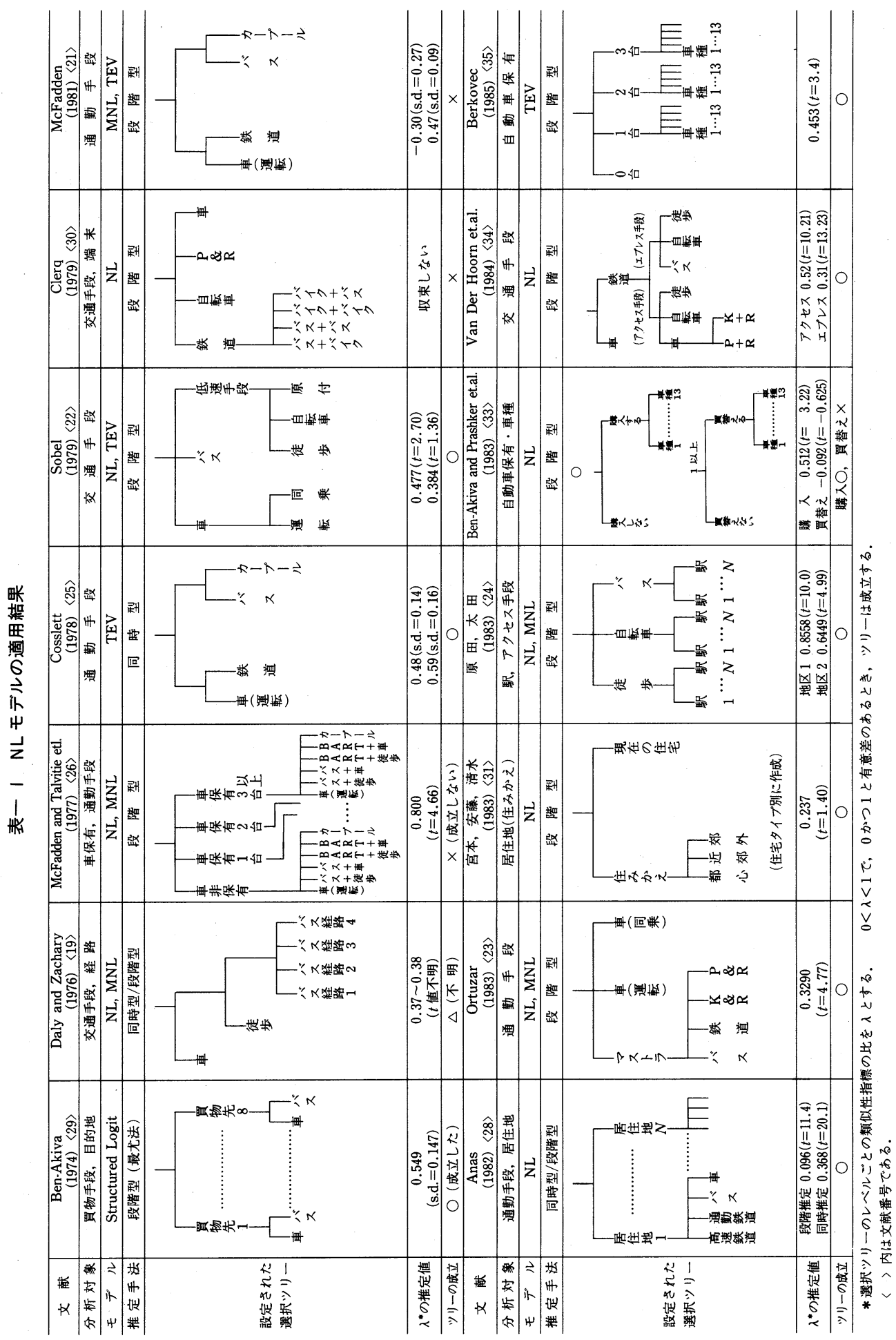


けて分析しうる予測体系が必要である。トリップ目 的によってあ推計フローが異なって来るはずである また, 非集計ロジットモデルに関する適用方法の改 善は, 同一タイプのモデル ( シェアモデル ) である グラビティモデルに応用するととが可能であり，集 計ロジットモデルを分担率曲線に替えて用いる事も 可能である.

逆に，非集計行動モデルに対する盲目的な期待は， 誤った認識として，一掃されなければならない。

「分析目的に適切なデータが準備できる事」が非集 計行動モデル分析においては特に重要であり，ある 政策の影響を捉えるには何を対象とするべきか, 分 析しようとする交通行動に対する計画者の見識が分 析の成否を決めるのである.

最後に, 本論文における成果は, 東京大学工学部 太田勝敏助教授の御指導と議論に負うとてろが大き く，ててに記して深謝の意を表します.

注 1）乙れは,「パラメータに関して線形」と 呼ばれるように, 変数を $X_{i}$, 効用を $V$ とすると,

$$
V=\sum_{i} \theta_{i} \cdot f\left(X_{i}\right)
$$

を意味している. したがって, 関数 $f$ の取り方によ り， $V$ を $X_{i}$ について非線形に設定できる.

注 2) パラメータ $(\eta, \omega)$ をむつ Gumbell 分 布の次の性質による.

$$
F(\varepsilon)=e^{-e^{-\omega(\varepsilon-\eta)}}, \omega>0
$$

を, パラメータ $(\eta, \omega)$ の Gumbell 分布とすると. $\left(\varepsilon_{1}, \varepsilon_{2}, \cdots \cdots, \varepsilon_{J}\right)$ がそれぞれパラメー夕( $\eta_{1}$, $\omega),\left(\eta_{2}, \omega\right), \cdots \cdots,\left(\eta_{J}, \omega\right)$ を持つ $J$ 個の独立 の Gumbell 分布に従う時, $\operatorname{Max}\left(\varepsilon_{1}, \varepsilon_{2}, \cdots \cdots\right.$, $\left.\varepsilon_{J}\right)$ あパラメータ $\left(\frac{1}{\omega} \ln \sum_{j=1}^{J} e^{\omega \eta_{j}}, \omega\right)$ の Gumbell 分布となる。

\section{参考 文 献}

1）原田 昇：非集計行動モデルの交通計画への 適用に関する研究, 東京大学都市工学科昭和 57 年度博士論文.

2）原田 昇・太田勝敏・新谷洋二：非集計行動 モデルによる新駅利用量の予測方法とその評 価, 土木学会論文集, 第 349 号 / IV - 1 , 昭和 59 年 7 月.

3）原田 昇：Nested Logit モデルの理論と適 用に関する研究のレビュー, 土木学会論文集, 第 353 号 $/ \mathrm{IV}-2$, 昭和 60 年 1 月.

4) R.D. Luce, P.Suppes : “ Preference, Utility, and Subjective Probability", in $\mathrm{Ha}$ ndbook of Mathematical Psychology, Vol. 3 , ed. R.D. Luce, and E. Galanter, New York, Wiley, 1965, pp. $249 \sim 410$.

5）原田 昇：改良ロジットモデルの交通計画へ の適用に関する研究 (日交研シリーズ A 93 ), 昭和 60 年 6 月, 日本交通政策研究会.

6）土木学会土木計画学委員会編：非集計行動モ デルの理論と実際 (土木計画学講習会テキス 卜, No. 15 , 昭和 59 年 11 月.

7) Domencich, T.A. and McFadden, D. : Urban travel demand - a bihavioral analysis, North-Holland, 1975 .

8) Manheim, M.L. : Fundamentals of transportation systems analysis, volume 1 : basic concepts, MIT. Press, 1979 .

9) Ruiter, E.R. and M.E. Ben-Akiva : Disaggregate Travel Demand Models for San Francisco Bay Area, TRR 673, 1978.

10) M.E. Ben-Akiva and R.C. Barras et al. : A Model System of Individual Travel Behavior for a Brazilian City, Transportation Policy Decision Making 2, pp. 451 480,1984 . 
11) M.E. Ben-Akiva and T.J. Atherton : Methodology of Short-Range Travel Demand Predictions Analysis of Carpooling Incentives, Journal of Transport Economics and Policy, pp. $224 \sim 267,1977$.

12) Amemiya, T.: On a two-step estimation of a multivariate logit model, Journal of Econometrics, pp. $13 \sim 21,1978$.

13) Manheim, M.L. : Practical implications of some fundamental properties of traveldemand models, HRR 422 , pp. $21 \sim 38$, 1973 .

14) M.E. Ben-Akiva and S.R. Lerman : Disaggregate Travel and Mobility-Choice Models and Measures of Accessibility, in Behavioral Travel Demand Model, ed. P. R. Stopher and Meyburg, 1976.

15）原田 昇：非集計ロジットモデルによる駅周 辺施設計画の評価, 第 17 回日本都市計画学 会学術発表会論文集, 都市計画別冊, 昭和57 年 11 月.

16) Williams, W.L.H.C.: On the formation of travel demand models and economic evaluation measures of user benefit, Environmental and Planning A. Vol. p. $285 \sim 344,1977$.

17) McFadden, D. : Working paper No.7617: properties of the multinominal logit model, Institute of Transportation Studies University of California, Berkeley, 1976 .

18) McFadden, D. : Quantitative methods for analyzing travel behavior of individuals : some recent developments, Working $\mathrm{Pa}$ per 7704. Urban Travel Demand Forecasting Project, Institute of Transportation Studies, University of California, Berkeley, 1977 .

19) Daly, A. and Zachary, S. : Improved mul- tiple choice models, LGORU, 1978.

20) Charles River Associates, lnc. : Disaggregate travel demand models, project 8-13: phase I report. Vol. I , II, C.R.A. 1976.

21) McFadden, D. : Econometric models of probabilistic choice, in Structural Analysis of Discrete Data with Econometric Application ed. C.F. Manski and D. Mc Fadden. MIT Press, 1981.

22) Sobel, K.N.: Travel demand forecasting by using the nested multinominal logit model, Transportation Research Record. 775 , pp. $48 \sim 55,1980$.

23) Ortuzar, J.D. : Nested logit models for mixed-mode travel in urban corridors, Transportation Research-A. Vol. 17, No. 4 , pp. $283 \sim 299,1983$.

24）原田 昇・太田勝敏：Nested Logit モデル の多次元選択への適用性 一 駅, アクセス手 段同時選択の場合 一, 交通工学, Vol. 18, No. 6, pp. $3 \sim 11,1983$.

25) Cosslett, S.R. : Efficient estimation of discrete-choice models, WP 7801 , Dep. of Econo. Univ. of California, 1978 .

26) McFadden, D. and Talvitie A. et al. : Demand Model Estimation and Validation, Special Report UCB-ITS-SR-77-9, The Institute of Transportation Studies, Univ. of Carifornia, 1977 .

27) Williams, H.C.W.L. and Ortuzar, J.D. : Behavioural theories of dispersion and the mis-specification of travel demand models, Transportation Research-B. Vol. 16 B, No. 3 , pp. $167 \sim 219,1982$.

28) Anas, A. : Residential Location Markets and Urban Transportation-Economic Theory, Econometrics and Policy Analysis with Discrete Choice Models, Academic 
Press, 1982 .

29) Ben-Akiva, M. : Structure of passenger travel demand models, Transportation Record 526, pp. $26 \sim 42,1974$.

30) Clerq, F. Le.: A model for Multimodal trips, in New Developments in Modelling Travel Demand and Urban Systems, ed. G.R.M. Jansen, et al., Saxon House, pp. $93 \sim 115,1979$.

31）宮本和明・安藤 淳 - 清水英範 : 都市圈住宅 立地需要予測モデル, 第 5 回土木計画学研究 発表会講演集, pp. $540 \sim 546,1983$.

32）林 良嗣・磯部友彦・冨田安夫：非集計手法 を用いた住宅需要分析モデル, 第 5 回土木計 画学研究発表会講演集, pp. 547 555,
1983 .

33) Ben-Akiva, M.E. and Prashker, J.N. et al. : Estimating and Use of Dynamic Transaction Models of Automobile Ownership, TRR 944 , pp. $134 \sim 141,1983$.

34) Van Der Hoorn A.I.J.M. et al. : Mode Choice and Mode Captivity in Interlocal commuting: Two Dutch Studies on Modal Split in Congested Transportation Corridors, Transportation Policy Decision Making 2, pp. $373 \sim 388,1984$.

35) Berkovec, J.: Forecasting Automobile Demand Using Disaggregate Choice Models, Trans. Res-B, Vol. 19 B, No.4, pp. $315 \sim 329,1985$. 